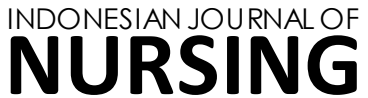 \\ PRACTICES
}

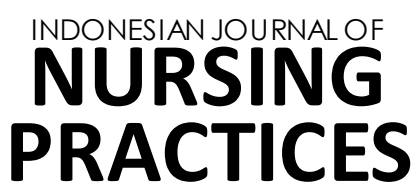

Junait ${ }^{1}$, Hery Djagat Purnomo², Chandra Bagus Ropyanto ${ }^{3}$

${ }^{1}$ Master Student of Nursing in Diponegoro University, and Senior Clinical Nurse at dr. Kariadi central Hospital of Semarang, Indonesia

${ }^{2}$ The Internist, the Consultant of Gastro-Hepatology in Kariadi cetral Hospital of Semarang ${ }^{2}$, Indonesia

${ }^{3}$ Lecturer of Nursing in Diponegoro University,

Semarang, Indonesia

Korespondensi: Junait

Email korespondensi:junaitns@gmail.com

\begin{tabular}{ll}
\hline Info Artikel & $:$ \\
Online & $:$ http://journal.umy.ac.id/index.php/ijnp \\
ISSN & $: 25484249$ (Print) \\
& $: 2548592$ (Online) \\
DOI & $: 10.18196 /$ ijnp.2173
\end{tabular}

\section{THE INFLUENCE OF USE ARTERY- FEMORAL BAND (ARFEBAND) TO HAEMATOM INCIDENT IN PATIENTS AFTER PERCUTANEUS CORONARY INTERVENTION (PCI)}

\begin{abstract}
Background: Haematoma is the main vascular complication in the patients after percutaneous coronary intervention (PCI). This incidents is important to be prevented and be overcome because the internal bleeding is not easy to be control and it can be make extend the mass of patients to inpatient in the hospital. Artery-femoral Band (arfeband) is a device designed that worthy and safe to keep the stability of haemostasis after PCI.
\end{abstract}

Aim: it is to know the influence of use arfeband to haematoma incidents in patients after $\mathrm{PCl}$.

Methods: this research used the quasy - experiment pre-post control trial design, it involves 121 patients after the elective of $\mathrm{PCl}$ that receives the intervention group (IG) and control group (CG) that is done for 6 hours after the removal of the sheath femoral artery, 60 IG used arfeband and 61 CG with the sand bag. The measurement of diameter haematoma is done when before and after intervention.

Results: this research shows that before the intervention, there are no differences that significant between IG and CG $p=0,909$. There are the significant differences to haem atom incidents after the use of IG with $P<0,05$, OR 0,398 with $\mathrm{Cl} 95 \%$ 0,172 - 0,919. It means that arfeband is reducing the haematoma incidents for 60,2\%. The size of the diameter of pre and post procedure, it is decrease in average of $30,4( \pm 13,6) \mathrm{mm}$ to be $10,9( \pm 15,9) p<0,05$.

Conclusion: The intervention of use arfeband influences to decrease the haematoma incidents significantly after percutaneous coronary intervention ( $P C \mathrm{Cl}$ ).

Keywords: arfeband, percutaneous coronary intervention (PCI), haematom.

\section{Background}

Percutaneous coronary intervention $(\mathrm{PCl})$ is one kind of procedure of revascularisation of coronary heart disease (CHD) (Kern, 2016; Rilantono, 2012; Schwartz, Burstein, Economides, Robert et al., 2011; Nuray, Umman, Arbal, Altok,
Enuzun, Uysal, Ncekara, Ulusoy, \& Baran, 2007; Woods, et al., 2005; Heintzen \& Strauer, 2009; and Gray, Dawkins, Morgan, \& Simpson, 2005).

The important thing in the medical act of $\mathrm{PCl}$ chooses of access of catheter coronary artery, the main operators that choose such as femoral 
artery, brachial artery, and radial artery. When the artery accesses are chosen, it is influenced by the experience, the skill of cardiology, indication and technique procedure, also vascular condition to minimalist the complication (Hassan, HasanAli, Demetry, Refaat, \& Ali, 2015).

Although transradial $\mathrm{PCl}$ have been proven that it is more safety and decrease the vascular complication in the catheter access, but it has not been welcomed and popular therefore it still used transfemoral (Hassan, Hasan-Ali, Demetry, Refaat, \& Ali, 2015).

Haematoma is one kind of incident that often happens between vascular complication accesses the heart catheter in patient after $\mathrm{PCl}$ (Kern, 2016; Vlasic, Almond, \& Massel, 2001; Armendaris, et al., 2008; and Sinaga, 2016).

Haematoma is the internal bleeding that is not easy to be control therefore because of the haematoma impact, the patient can be lose more their blood from $500 \mathrm{ml}$ without detected first, especially for the patient obesity who have the big thighs (Vaitkus, 2004; Augustin \& SarmentoLeite, 2010; Gregory, Midodzi, \& Pearce, 2013; and Jones, et al., 2002).

There are many devices that is offered as the alternative of standard procedure with pillow health, vascular closure device such as, haemostasis pads, FemoStop, Clamp Ease, Mynx,

\section{Method}

Method of the research that used in this research is quasy- experiment with pre-post control trial design method with the sample of 124 patients after the elective $\mathrm{PCl}$ that has inclusion criteria, the age of the respondent is $40-65$ years old, the right of femoral artery access, the size of sheath femoral 7 French, and one times of puncture. The exclusion criteria, they are suffered procedural complication (acute myocardial infarction or severe chest pain, severe bleeding, ventricular fibrillation), he modynamic instability, coagulation disorders, the loss of consciousness. Three of 124 patients are
Duett, Boomerang, ExoSeal, Starclose, VasoSeal, Angio-Seal and Perclose devices (Schwartz, Burstein, Economides, Robert et al., 2011; Jones, et al., 2002; Kimmel \& Jessse, 2007; Travis, Dey, Albrecht-Gallauresi, Brindis, Shaw, Weintaub, \& Mitchel, 2005; Yilmaz, Gurgun, \& Dramali, 2007; Hyyh, 2012; Behan, 2006; Trabattoni, et al., 2011; and Mohammed, Said, \& Salah, 2013), but those device is less popular to use in Indonesia with the some consideration likes the efficiency of that device.

Arfeband (artery-femoral band) is local device compression of femoral artery that is designed with more the consideration of safety, the patient safety and also the efficiency of device from the other devices. This research used arfeband that compared with the pillow health in the 92 patients after angiography coronary with randomized controlled trial method that more effective to prevent hematoma incident (Junait \& Sodiqur, 2013). This research is continued to the patient after $\mathrm{PCl}$ who have the vascular complication risk because of they get antithrombotic therapy aggressively before, during, and after the medical act, also the size of femoral sheath is the largest (Nuray, Umman, Arbal, Altok, Enuzun, Uysal, Ncekara, Ulusoy, \& Baran, 2007; Han \& Cho, 1999; and Matic, et al., 2015; Chair, et al., 2005). The purpose of the research is to know the influence of use arfeband to haematoma incidents in patients after $\mathrm{PCl}$.

executed. 121 patients are divided at random with simple random sampling into two groups, the handling group with arfeband 60 (IG) and the control group with the sand bag 61 (CG). The observation and the measurement of haematoma diameter are done before and after intervention, the measuring instruments that used, they are observation paper, tensiometer, and the meter that used to measure the cloth. The experimental instrument has been checked and approved by the ethical clearance committee; all patients are given informed consent for inclusion in the study. 


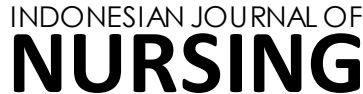 \\ PRACTICES}

The Flow of Research

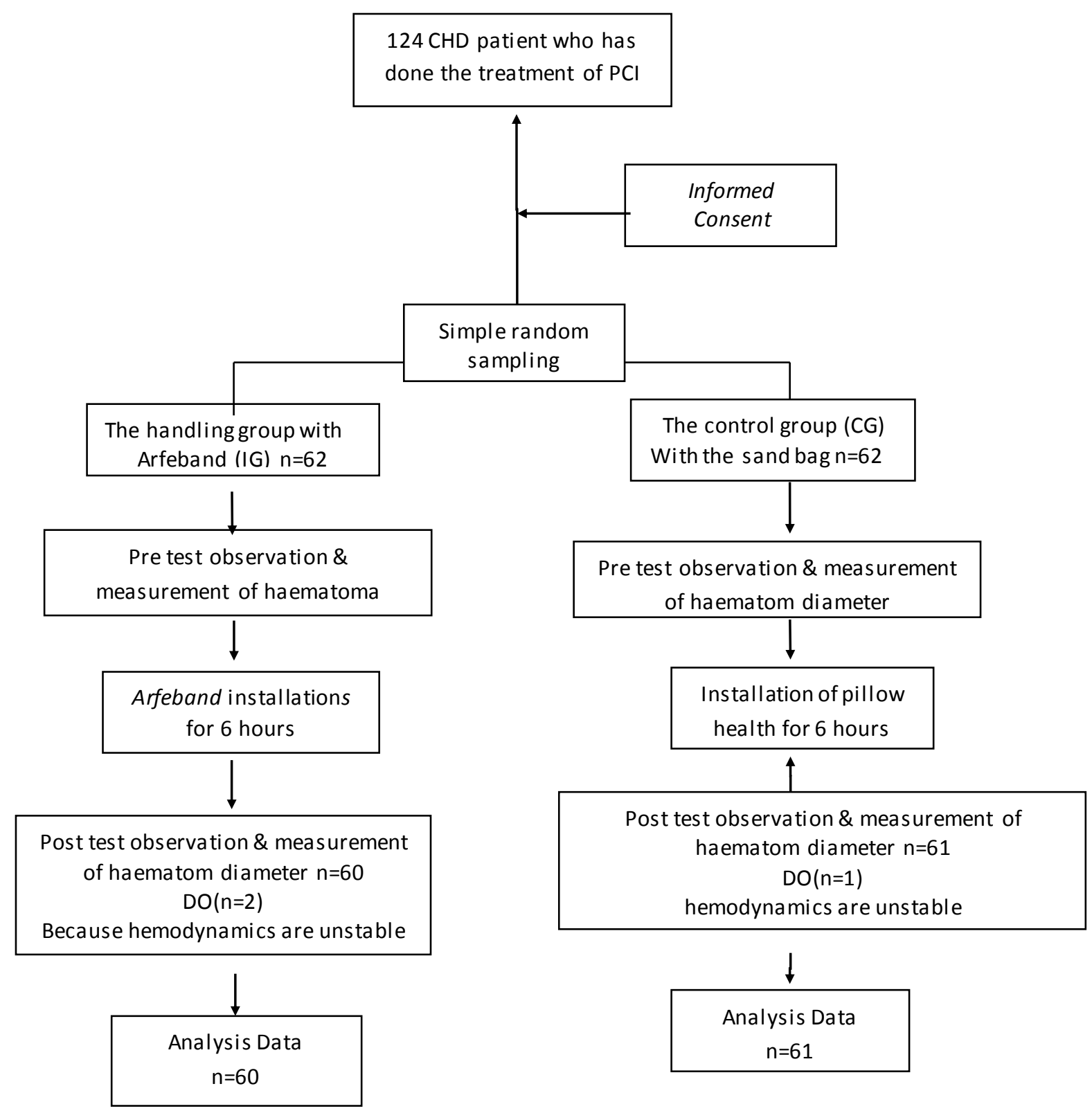

Picture 1. The Flow of Research

\section{Result}

From this research, the researcher found 121 respondents that consist of $60 \mathrm{IG}$ and $61 \mathrm{CG}$. The characteristic of demography and the basic cl inic that influenced the hematoma incidents from both of group test is summarized in Table 1 . 


\section{The characteristics of the subject}

Table 1 . The demography data and clinical characteristic in patient that influenced to haematom incidents ( $n=121)$

\begin{tabular}{lcccc}
\hline Characteristics & $\begin{array}{c}\text { Handling (IG) } \\
(\mathrm{n}=60)\end{array}$ & $\begin{array}{c}\text { Control (CG) } \\
(\mathrm{n}=61)\end{array}$ & $\begin{array}{c}\text { Total } \\
(\mathrm{n}=121)\end{array}$ & p-value \\
\hline Gender & & & & 0,098 \\
$\quad$ Male & $49(81,7 \%)$ & $52(85,2 \%)$ & $101(83,5 \%)$ & \\
$\quad$ Female & $11(18,3 \%)$ & $9(14,8 \%)$ & $20(16,5 \%)$ & \\
Ages & & & & 0,059 \\
$\quad$ Means & 57,32 & 56,77 & 57,04 & \\
$\quad$ Deviation Std & $\pm 6,28$ & $\pm 8,211$ & $\pm 7,29$ & 0,142 \\
MAP (mmHg) & & & & \\
$\quad$ Means & $14(87,5 \%)$ & 68,2 & 69,5 & \\
$\quad$ Deviation Std & $2(12,5 \%)$ & $\pm 6,34$ & $\pm 7,20$ & \\
Heparin Dose (international unit) & & & \\
$\quad$ Median & 7000 & 7000 & 7000 & \\
$\quad$ Minimum & 5500 & 5000 & 5000 & \\
$\quad$ Maximum & 8000 & 9000 & 9000 & 0,400 \\
BMI & & & & \\
$\quad$ Means & 25,32 & 25,26 & 25,19 & \\
$\quad$ Deviation Std & $\pm 2,85$ & $\pm 3,99$ & $\pm 2,93$ & \\
& & & &
\end{tabular}

About of $83,5 \%$ the respondents are male who has aged average $57,04( \pm 7,29)$ years old. The main arterial pressure (MAP) is $69,5( \pm 7,20)$ $\mathrm{mmHg}$ and (the body mass index (BMI) of the patient averaged in $25,19( \pm 2,93) \mathrm{kg} / \mathrm{m} 2$. The dose of heparin that is given when the medical action of $\mathrm{PCl}$ is at most 7000 international units (iu) the lowest dose of $5000 \mathrm{iu}$, and the highest 9000iu

Table 2. The analysis result pre effectively procedure of IG vs CG to haematom incidents ( $n=121$ )

\begin{tabular}{|c|c|c|c|c|c|c|}
\hline & & \multicolumn{4}{|c|}{ Haematom PRE } & \multirow[t]{2}{*}{$p$} \\
\hline & & \multicolumn{2}{|c|}{ Yes } & \multicolumn{2}{|c|}{ No } & \\
\hline & & $\mathrm{n}$ & $\%$ & $\mathrm{n}$ & $\%$ & \\
\hline \multirow{2}{*}{ Groups } & (IG) & 23 & 38.3 & 37 & 61.7 & 0,909 \\
\hline & (CG) & 24 & 39.3 & 37 & 60.7 & \\
\hline Total & & 47 & 27.3 & 88 & 72.7 & \\
\hline
\end{tabular}

After removal of sheath femoral and before the intervention has been observed, there are the hematoma incidents in the puncture site. From this observation, there are IG $23(38,3 \%)$ vs CG 24 (41\%) that is showed in the table 2 . Before the intervention procedure is done, the researcher also measures the hematoma diameter average in IG $30,4( \pm 13,6) \mathrm{mm}$ vs CG $30,8( \pm 21,8) \mathrm{mm}$. Then the measurement of hematoma is done after 6 hours of intervention and there is of decrease of diameter between IG 10,9 $( \pm 15,9) \mathrm{mm}$ vs $\mathrm{CG} 27,5( \pm 21,7) \mathrm{mm}$ that is showed in table 3. 


\section{NUDRSINANG \\ PRACTICES}

Table 3. The analysis result of post procedure of the affectivity IG vs CG to haematom incidents ( $n=121)$

\begin{tabular}{|c|c|c|c|c|c|c|c|}
\hline & & \multicolumn{4}{|c|}{ Haematom POST } & \multirow[t]{2}{*}{$P$} & \multirow[t]{2}{*}{ OR (Cl 95\%) } \\
\hline & & \multicolumn{2}{|c|}{ Yes } & \multicolumn{2}{|c|}{ No } & & \\
\hline & & $\mathrm{n}$ & $\%$ & $\mathrm{n}$ & $\%$ & \multirow{4}{*}{0,029} & \multirow{4}{*}{$0,398(0,172-0,919)$} \\
\hline \multirow{2}{*}{ Groups } & (IG) & 11 & 18.3 & 49 & 81.7 & & \\
\hline & (CG) & 22 & 36.1 & 39 & 63.9 & & \\
\hline Total & & 33 & 27.3 & 88 & 72.7 & & \\
\hline
\end{tabular}

\section{Analysis}

The result of the research showed that both of those groups are comparable. There is no differences that significant in the basic characteristics and characteristics clinic in the patients $(p>0,05)$. Before the intervention of hematoma incident is done, there is no differences that significant between both of those groups $(p>0,05)$ that is showed in table 2 . After the intervention has been done for 6 hours and re-observed to hematoma incidents that is showed in table 3 , the test result of chi-squaree procedure, it shows that there are the significance differences between both of groups. They are $p<0,05$, OR $0,398 \mathrm{Cl} 95 \%(0,172-0,919)$. It means that IG is able to prevent the hematoma incidents to $60,4 \%$.

Based on the result of statistic test especially in the change of the size of diameter pre and post procedure, it concluded that IG $p=0,001$ vs CG $p>0,05$, it means that there are the change of the size of the hematoma diameter if it used IG that compared with CG, seen the table 4 .

Table 4. The analysis result of the effect IG to the change of the size of diameter in all patient with hematoma incidents $n=121$

\begin{tabular}{cllccc}
\hline & Groups & $\mathrm{n}$ & $\begin{array}{c}\text { Median (min-max) } \\
(\mathrm{mm})\end{array}$ & $\begin{array}{c}\text { Means } \pm \text { SD } \\
(\mathrm{mm})\end{array}$ & $P$ \\
\hline \multirow{2}{*}{ IG } & Preprocedure & 60 & $30,0(10-60)$ & $30,4( \pm 13,6)$ & 0,001 \\
& Postprocedure & 60 & $0(0-5)$ & $10,9( \pm 15,9)$ & \\
CG & Preprocedure & 61 & $20,0(1-10)$ & $30,8( \pm 21,8)$ & 0,544 \\
& Postprocedure & 61 & $25(0-10)$ & $27,5( \pm 21,7)$ & \\
\hline
\end{tabular}

\section{Discussion}

According to the table 1, the demography factor and the basic clinic condition of patients, it shows that the refraction selection does not happen because of the adequate randomization. The tests are randomly controlled, IG that used the simple of the local device of femoral artery, it shows that the procedure that used in this research has the high success with significant to prevent hematoma incident in patient $\mathrm{PCl}$ after the removal of the sheath femoraltherefore it is more working than uses the sand bag in standard procedure.

There are differences that significant between the advantages of the use of arfeband in the patient after $\mathrm{PCl}$ and the control group in the 
prevent of hematoma incident, that is IG $11(18,3 \%)$ vs CG $22(36,1 \%), p<0,05$. Meanwhile, for the change of the size of hematoma diamete $r$ before and after of the device use, there are differences that significant. That is $30,4 \mathrm{~mm}$ to be $10,9 \mathrm{~mm}(p=0,002)$ vs $30,8 \mathrm{~mm}$ to be $27,5 \mathrm{~mm}$ $(p>0,05)$.

The main factor that becomes the factor of hematoma incident to be less is the advantage of IG position since it is more stable in the area of pressure. It is not easy influenced by the movement of the patient and the pressure that gives more relative constant and measurable if it is compared with the sand bag. Several of the great researches have been compared the hemostasis strategy vascular access in patient who is going to the elective percutaneous coronary procedure.

Several devices have been developed to help in the closure of femoral arteriotomy lesions, including extravascular covering devices such as Vaso Seal, Angio Seal, and Exo Seal. There are some device that used such as Percutaneous closure suture device, and mechanical suppressor devices (Hassan, Hasan-Ali, Demetry, Refaat, \& Ali, 2015). The mechanical compression devices that often to use are C-clamp or compresor and pneumatic Femostop device. All of these devices are not to be choosing because the efficiency reason therefore people choose the manual pressure that is continued by the pressure of the sand bag. Arfeband is cheaper than all devices that often are used and it is easy to be made. When people made one arfeband, it needs $20 \$$ and it is used repeatedly. All of devices included the arfeband, are given with the constant pressure in the injuries area and still keep peripheral distal perfusion in the right leg in the dorsalis pedis pulse.

Arfeband has advantages to be the local alternative device and replacement the sand bag like to the early mobilization therefore the comfort of the patient is kept with right and left tilt without changing the quality of pressure. It also is designed to keep everything possible.

\section{Conclusion}

The result of this study shows that arfeband is simple device and effective as the alternative device to reach homeostasis and prevent the hematomas incident after $\mathrm{PCl}$. The effects of the arfeband use are reasonable and safe to keep the stabilization of homeostasis after PCl. The use of arfeband is done as an independent nurse in the treatment of injuries access a catheter heart.

Conflict of interest: There is no conflict of interest.

Ethical approval: Approved by the Institutional Com-mittee on Human Research at the institution

\section{References}

Armendaris, et al,. (2008). Incidence of Vascular Complications In Patients Submitted to Percutaneous Transluminal Coronary Angioplasty by Transradial and Transfemoral Arterial Approach. Acta Paul Enferm. Vol. 21 no1 Sao Paulo Jan.

Arora N, et al. (2002). A propensity analysis of the risk of vascular complications after cardiac catheterization procedures with the use of vascular closure devices Am Heart J:153:606211.

Augustin, A. C., de, Q. A. S., \& Sarmento-Leite, R. E. (2010). Early sheath removal and ambulation in patients submitted to percutaneous coronary intervention: a randomised clinical trial. International Journal of Nursing Studies; 47, 8, 939-45.

Baker, N. C., Escarcega, R. O., Lipinski, M. J., Magalhaes, M. A., Koifman, E., Kiramijyan, S., Negi, S. I.,. Waksman, R. (2016). Active Versus Passive Anchoring Vascular Closure Devices Following Percutaneous Coronary Intervention: A Safety and Efficacy Comparative Analysis. Journal of Interventional Cardiology; 29, 1, 108-112. 


\section{NURSSING \\ PRACTICES}

Behan MWH. (2006). A Randomised controlled trial comparing the routine use of an angio-seal sts device strategy with conventional femoral haemostasis methods in a district general hospital, doi : 10.1111/j.1742-1241.2006.01229.

Chair, et al. (2015). The clinical effectiveness of length of bed rest for patients recovering from transfemoral cardiac catheterization. International Journal of Evidence-based healthcare Volume 6 Issues 4: 2005, page 352-390.

Ganeshan AG. (2007). Angioseal versus manual compression for haemostasis following peripheral vascular diagnostic and interventional procedures a randomized controlled trial. European Journal of Radiology; Vol. 61(2).

Gregory BG, Lester KK, Gregory DM, Twells LK, Midodzi WK, and. Pearce NJ. (2016). Impact of body mass index on short-term outcomes in patients undergoing percutaneous coronary intervention in Newfoundland and Labrador, Canada. Cardiology Research and Practice.

Gregory, D. E. B. O. R. A. H., Midodzi, W. I. L. L. I. A. M., \& Pearce, N. E. I. L. (2013). Complications with Angio-Seal ${ }^{\mathrm{TM}}$ Vascular Closure Devices Compared with Manual Compression after Diagnostic Cardiac Catheterization and Percutaneous Coronary Intervention. Journal of Interventional Cardiology; 26, 6, 630-638.

Hassan, A. K. M., Hasan-Ali, H., Demetry, S. R., Refaat, R., \& Ali, A. S. (March 01, 2015). Early sheath removal after percutaneous coronary intervention using Assiut Femoral Compression Device is feasible and safe. Results of a randomized controlled trial. The Egyptian Heart Journal, 67, 1, 69-77.
Heintzen MP, Strauer BE. (2009). Local vascular complications after cardiac catheterization.

Han JK, Cho KJ,. (1999). A comparative study between the application group and nonapplication group of a sand bag on the surgical region after a pediatric cardiac catheterization. Korean Journal Child Health Nurse. Oct;5(3):340-348.

Hyyh AE,. (2012). Randomized, controlled trial, to assess the efficacy of two vascular compression techniques in reducing complications at vascular access sites after therapeutic or diagnostic, Arch Cardiol Mex; 82(2):105-111

Jones, et al,. (2002). Effectiveness of mechanical compression devicesin attaining hemostasis after femoral sheath removal. American Journal of Critical Care, March 2002, Volume 11, no. 2.

Junait, Sodiqur, R,. (2013). Perbandingan efektifitas antara bantal pasir dan arfeband sebagai penekan luka pasca angiografi koroner, Medica Hospitalia, Journal of Clinical Medicine, Vol 2 (1): 50 53.

Kimmel, S.E., dan Jessse, E.. (2007). Risk of major complication from coronary angioplasty performed immediately after diagnostic coronary angiography: result from the registry of the society for cardiac angiography and interventions. Journal ACC, 2007. volume 30 No 1.

Kern MJ. (2016). The interventional cardiac catheterization handbook. 6th ed. Saunders Elsevier. Philadelphia.

Lansky A, Mehran R, Dangas G, Shirai K, Costa R, Costantini C, Tsuciya Y, Mintz G. (2009). Comparison differences in outcaome after percutaneous intervention in men versus women $<40$ years of age. The american Journal of Cardiology, volume 93, 2009, issue 7, Pages $916-919$. 
Matic DM, et al. (2015) Incidence, predictors and prognostic implications of bleeding complicating primary percutaneous coronary intervention, Original Article, Vojnosanit Pregl; 72(7): 589-595

Mohammed H, Said H and Salah M. (2013). Determining best nursing practice: effectiveness of three groin compression methods following cardiac catheterization. Journal of American Science; 9(6)

Numasawa $Y$, Kohsaka S, Miyata $H$, Noma $S$, Suzuki M, IshikawaS, et al. (2015). Gender differences in in-hospital clinical outcomes after percutaneous coronary interventions: An Insight from a Jap ane se Multicenter Registry. PLOS ONE 10(1):e0116496.

doi:10.1371/journal.pone.0116496

Nuray, Umman, Arbal, Altok, Enuzun, Uysal, Ncekara, Ulusoy, \& Baran, . (2007). Nursing care guidelines in percutaneous coronary and valvularintervention. Turkish Society of Cardiology ISBN 9944-5914-2-4, 2007.

Schwartz BG, Burstein S, Economides C, Robert et al. (2011). Review of vascular closure devices. Cath Lab Digest. Volume 19 Issue 7 - July 2011, Pages: 1, 10-20.

Sinaga J. (2016). Perbandingan efektifitas penekanan bantal pasir antara 2, 4, dan 6 jam terhadap komplikasi pada klien pasca kateterisasi jantung (a random controlled trial), Tesis, FIK UI, diakses dari http://garuda.dikti.go.id/ pada tanggal 20 Juli 2016

Trabattoni, et al,. (2011). A New Kaolin-based haemostatic bandage compared with manual compression for bleeding control after percutaneous coronary procedures, Eur Radiol; 21:1687-1691
Travis, Dey, Albrecht-Gallauresi, Brindis, Shaw, Weintaub, \& Mitchel,. (2005). Risk of local adverse events following cardiac catheterization by haemostasis device Use. Journal Invasive Cardiol. 2005 Dec;17(12):644-650

Vaitkus, P. T. (2004). A meta-analysis of percutaneous vascular closure devices after diagnostic catheterization and percutaneous coronary intervention. The Journal of Invasive Cardiology, (2004); 16, 5, 243-6.

Vlasic W, Almond D, Massel D. (2001). Reducing bedrest following arterial puncture for coronary interventional procedure-impact on vascular complications: The BAC Trial. Journal of Invasive Cardiology Volume: 13 Publication Date: Dec 052001.

Woods, et al. (2005). Cardiac nursing. (5th Edition). Philadelphia: Lippincott Williams \& Wilkins.

Yilmaz, Gurgun, Dramali,. (2007). Minimizing short-term complications in patients who have undergone cardiac invasive procedure: a randomized controlled trial involving position change and sandbag. Unadolu Kardiyol derg 2007; 7: 390-396. 